\title{
TURDUS ROSEUS.
}

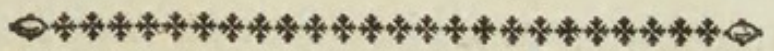

\section{CHARACTER GENERICUS.}

Roftrun tereti-cultratum : mandibula fuperiore apice deflexo, emarginato.

Nares nudx fuperne membranula femitectæ.

Faux ciliata.

Lingua lacero-emarginata.

$$
\text { Lin. Syft. Nat. p. } 291 .
$$

CHARACTER SPECIFICUS, \&\%。

TURDUS ROSEUS, capite alis caudaque nigris, occipite criftato.

TURDUS fubincarnatus, capite alis caudaque nigris, occipite criftato.

$$
\text { Lin. Syf. Nat. p. } 294 .
$$

MERULA ROSEA.

Aldr. orn. 2. p. 626.

Non modo in Italia et reliqua mitiori Europa, fed et in aliis mundi partibus innatus, raro admodum in Angliam defertur Turdus rofeus. Æqualis fere fturno eft magnitudine, fumma notabilis elegantia ; capite nimirum, collo, cauda alifque nigrantibus, variata luce, fplendide viridi-purpureis; reliqua avi

$\mathrm{E}$ 
pulcherrime rofeo-pallente. Infectis, ut plurimum, vefcitur hæc avis: maxime autem frvit in varias gryllorum fpecies; eamque quafi facram habent nonnulli Orientis incolæ, Hierapolitæ præcipue, quod minuat quodammodo diram animalculorum formidoloforum fegetem. Pulchrum turdi rofei fpecimen, in agro Oxonienfi anno proxime elapfo fcloppeto confectum, amiciffime nobifcum communicavit Dominus Jenner, militum clafficorum dux. 


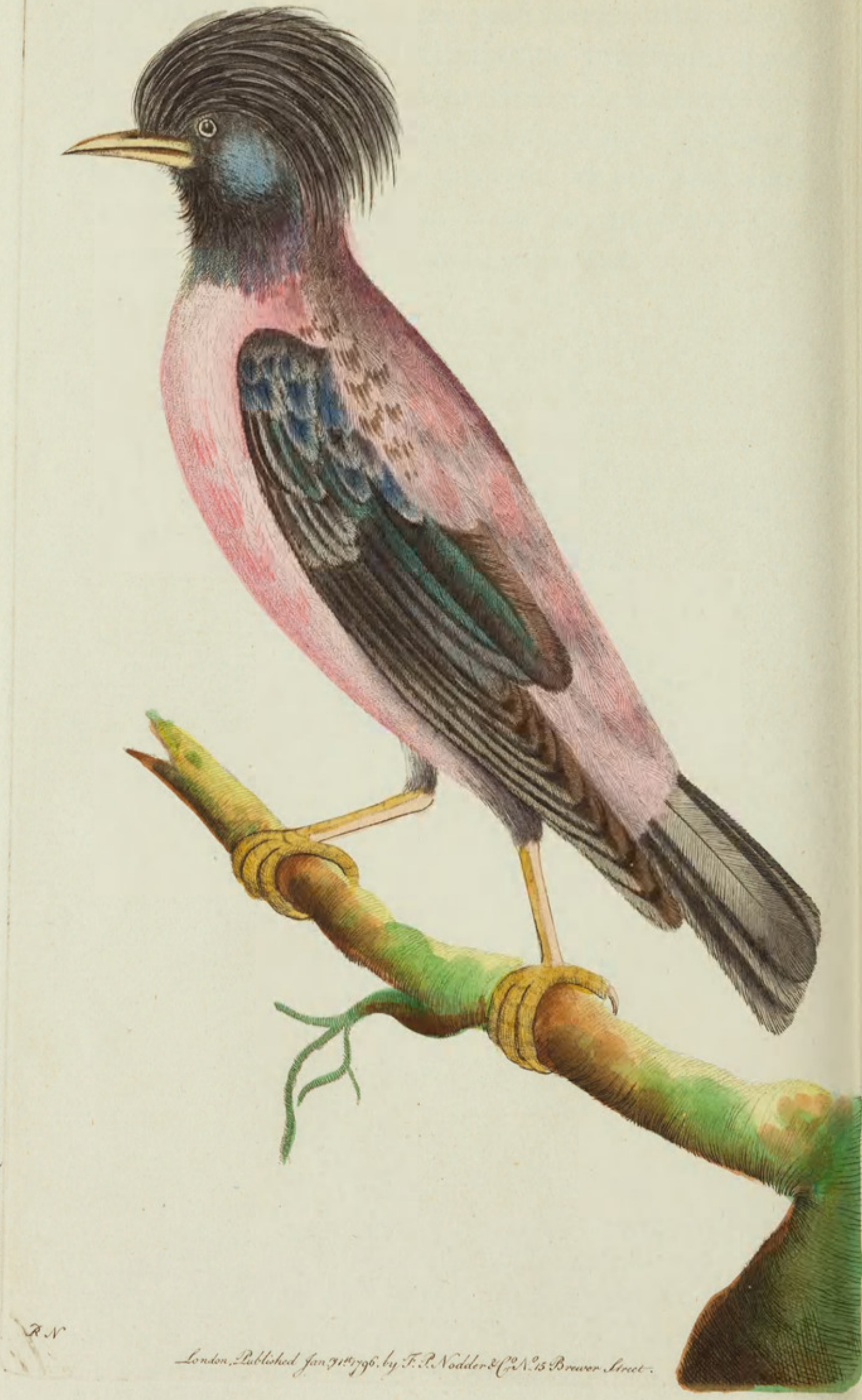
$\mathrm{THE}$

\section{ROSE-COLOURED OUZEL.}

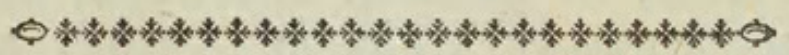

GENERIC CHARACTER.

Bill Atrait, obtufely carinated at top, bending a little at the point, and flightly notched near the end of the upper mandible.

Noftrils oval.

Tongue flightly jagged at the end.

SPECIFIC CHARACTER, EंC.

ROSE-COLOURED, CRESTED THRUSH, with the head, neck, wings, and tail black. The ROSE-COLOURED OUZEL.

Will. orn. p. 194.

Le MERLE COULEUR de ROSE.

$$
\begin{aligned}
& \text { Briff. 2. p. } 250 \text {. n. } 20 . \\
& \text { Buff. oif. 3. p. } 348 \text {. pl. } 22 .
\end{aligned}
$$

The rofe-coloured ouzel, a native of Italy and the warmer regions of Europe, as well as of many other parts of the globe, in England appears only as an occafional vifitant : its fize is nearly that of a ftarling: it is highly remarkable for the elegance of its E 2 colors : 
colors: the head, neck, wings, and tail being black, with varying gloffes of green and purple, while the remainder of the bird is of a beautiful pale rofecolor. It feeds, in general, on infects, and efpecially on the different kinds of locufts; for which reafon it is confidered as a kind of facred bird in fome of the Eaftern countries, where it contributes greatly to the deftruction of thofe noxious animals. This is faid to be particularly the cafe in the neighbourhood of Aleppo. A beautiful fpecimen of this bird was thot in the courfe of the laft year in $\mathrm{Ox}$ fordhire, of which an account was politely communicated by Captain Jenner, of the marines. 


\section{$2 \mathrm{BHL}$ Biodiversity Heritage Library}

Shaw, George. 1796. "The Rose-Coloured Ouzel, Turdus roseus [PI. 231]." The Naturalist's Miscellany 7(LXXVIII), https://doi.org/10.5962/p.310774.

View This Item Online: https://www.biodiversitylibrary.org/item/276356

DOI: https://doi.org/10.5962/p.310774

Permalink: https://www.biodiversitylibrary.org/partpdf/310774

\section{Holding Institution}

Museums Victoria

\section{Sponsored by}

Atlas of Living Australia

\section{Copyright \& Reuse}

Copyright Status: Public domain. The BHL considers that this work is no longer under copyright protection.

This document was created from content at the Biodiversity Heritage Library, the world's largest open access digital library for biodiversity literature and archives. Visit BHL at https://www.biodiversitylibrary.org. 